ISSN(print): 2643-9840, ISSN(online): 2643-9875

Volume 03 Issue 11 November 2020

DOI: 10.47191/ijmra/v3-i11-09, Impact Factor: 5.522

Page No.- 253-259

\title{
Evaluation of National Values and Abay's Teaching
}

\author{
Anarkul Bekmyrzakyzy Salkynbay ${ }^{1}$, Ulzhan Usenkyzy Anarbekova ${ }^{2}$ \\ ${ }^{1}$ Doctor of philological sciences, Professor, Al-Farabi Kazakh National University, Kazakhstan \\ ${ }^{2}$ Doctoral student, Al-Farabi Kazakh National University, Kazakhstan
}

\begin{abstract}
Value is the spiritual core of the worldview, the basis that allows us to understand the historical causes and meaning of the various situations that arise in society, the main balance should be this value. After all, these are the national values that determine the uniqueness and originality of the people or ethnic group. In today's globalized world, the study of national values, the analysis of its meaning and significance, the systematization of spiritual and cultural codes, the assessment of traditions and beliefs, the promotion of virtues that play an important role in society - play a major role in ensuring the tolerance.

National values are important not only for the nation but also for the broad horizons of human culture, the breadth of breath, the height of the pedestal. It is important for the harmonious development of mankind. Evaluation of the value is an important phenomenon that determines the meaning of life. Evaluation of the value can be used to determine the direction and route of large and small events and situations around them, to analyse the dynamics of social, cultural and even political processes, and to provide a systematic interpretation. The article explores the importance of assessing and promoting national values through Abay's teachings.
\end{abstract}

KEYWORDS: nation, national values, national consciousness, axiology, assessment of national values

\section{INTRODUCTION}

It is a great responsibility to talk about the concepts of nation, national identity, national spiritual values, national honour, national symbol, national character, and national traditions. It is necessary to analyze the relationship between the concepts of "globalization" and "nation". Interestingly, as the issue of globalization arose and all the information began to speak about it, the issue of the nation and its study became more relevant. The fact that the broad movement of ethnic and national issues is one of the leading global problems is widely discussed both in scientific research and in the daily world press. Surprisingly, even in the world's most civilized nations, there is a deep internal crisis. There is a widespread "renaissance" of ethnicity and religiosity, which often sees the nation as the development of an ethnic group and defines the characteristics of these social groups through a common language, territory or region, a common culture. The complexity of the problem is obvious not only in practice but also in theory. Almost all modern researchers have different opinions in the analysis of national and ethnic concepts, the specifics of their use, weigh their own scientific hypotheses.

National values are important not only for the nation but also for the broad horizons of human culture, the breadth of breath, the height of the pedestal. It is important for the harmonious development of mankind. Evaluation of the value is an important phenomenon that determines the meaning of life. Evaluation of the value can be used to determine the direction and route of large and small events and situations around them, to analyze the dynamics of social, cultural and even political processes, and to provide a systematic interpretation.

Value is the spiritual core of the worldview, the basis that allows us to understand the historical causes and meaning of the various situations that arise in society, the main balance should be this value. After all, these are the national values that determine the uniqueness and originality of the people or ethnic group. In today's globalized world, the study of national values, the analysis of its meaning and significance, the systematization of spiritual and cultural codes, the assessment of traditions and beliefs, the promotion of virtues that play an important role in society - play a major role in ensuring the tolerance.

\section{MAIN PART}

Scientists have great confidence in the neo-existentialist theory that emerged at the turn of the twentieth and twenty-first centuries and the beginning of the twenty-first century. It is gratifying that among them there are not only philosophers but also 


\section{Evaluation of National Values and Abay's Teaching}

many psychologists who oppose the theories proposed by the theories of naturalism and psychoanalysis. Currently, this theory is being actively studied in the West. The existential approach is widely used in philosophy, pedagogy, ethnography, cultural studies and even medicine. The creation of existential axiology, a specially created principle that studies the degree of influence on the subject through "values" is now emerging as a scientific direction. It has a great ideological significance in the context of the information society. Valuation and evaluation of value systems will be important for all activities, from the daily life of mankind to the solution of major global problems. Because, as Abay said:

Bring a bridegroom, marry a girl, and have a wedding

Introduce a girl - people are fond of interesting.

In hemp, there are zhar-zhar, betashar,

Will they be interesting flowers without poems?

Poetry opens the door to the world at birth,

The body enters the earth with a poem,

All the fun in life is in the poem,

Come to think of it, don't just live in vain. (Meaning translation by authors)

If we recognize the customs, traditions, culture transmitted through poetry in Kazakh as values, then from birth, the relationship between the objective laws of reality and the formation of subjective qualities of the individual is closely linked with the assessment of values. For a person who does not think who "just live in vain", the value is probably small. For an individual who seeks the meaning of life, thinks, and feels the good light of goodness, the recognition of value will also have a special meaning. Defining the role of values in the life of the individual and society underscores the need for existential axiology, which includes not only ethical and aesthetic but also anthropological and ontological issues.

Existential axiology (axios - has a value; logos - mind, theory) - the study of the individual and his ontological development, personal development and its development in society, social environment, cultural and spiritual state, the relationship between human nature and nature. It ranges from a simple understanding of the value of the individual to the understanding of its impact on the environment and social life. The source of the human aspiration for self-knowledge and development is associated with the recognition and appreciation of the values formed by the national worldview.

Researchers point to two main areas of existential axiology:

- Values perceived through the inner nature of the individual, the study of the creative potential of the individual, the interpretation of the subjective nature of values;

- Study of the value bases of social life in general, the development of social axiology and historical axiology.

At the beginning of the XXI century, both scientists and society began to talk about the "crisis of values", the need to reevaluate values and find a new way to find a new meaning in human life. Each generation brings new goals and aspirations, continuing the process of forming the worldview of society. How are the changes in our daily lives qualitatively different? To answer these questions, we will need to specify the following:

- $\quad$ to analyze the role of values in the development of society;

- $\quad$ to determine the essence of the traditional classical values of the individual and civilization;

- It is necessary to show the value priorities of the modern era.

Man is a thinker. A person is an active being who has his own purpose, way, traditions and customs, plans and goals.

A few words about the emergence of axiology as a special branch of philosophy. It is said that axiology began to take shape in the second half of the XIX century. The term was introduced in 1902 by the French philosopher P. Lapi [6. 128], and in 1904 E. von Hartmann used the term to refer to a branch of philosophy that deals with values [7. 28-45].

Although the term "axiology" was not used, the first idea of value began to take shape in ancient philosophy. Axiology, in fact, is as ancient as philosophy itself.

To talk about value, we must first define its definition. Many scientists in the world of philosophy have given a scientific opinion and definition of value. Most scientists recognize a value as something important to a person's interests, desires, aspirations, and a person or group of people.

According to scientists, first of all, value, like truth, is not a quality. Value is the relationship between thought and reality.

Kazakh scientist A. Aitaly, in his research work "Ulttanu" (Nation studies) he rightly called a need for the formation of a new branch of "Ulttanu" and writes, "To tell nation's history as an example of common heroism and wisdom, or to portray it as a victim of history, to explain the hardships of the nation only by the evil intentions of the colonizers and invaders, educates the nation in a destructive spirit" [5. 7-8].

There are many negative articles about Abai, a thinker who once spoke about the ignorance of the Kazakhs... The question of whether modern Kazakh is better than the Kazakh mentioned by Abai should concern everyone. In the spirit of independence, 


\section{Evaluation of National Values and Abay's Teaching}

did we develop production and mandate agriculture? Today's Kazakh, who rejoiced in Golovkin's victory and rejoiced with Ilya Ilyin, said If our Kazakh comes in front of a horse, wins a wrestler, takes a bird, catches a dog ahead of others, he will be happy. I don't know, is there more joy than that? Oh, maybe not! What is the reason for all this joy in the Kazakh sister to be proud of the fact that the art of one animal is overgrown or someone else's? He is not the one who overtook, the one who fell, or not his son. All this means that the Kazakhs have no enemies other than the Kazakhs, they want to be happy as if they did something great, and they want to annoy others. To offend someone is forbidden in the Shari'a, it is harmful to the peasantry, it is irrational. Why do they get happiness by offending others? Or, why the person who got offended should feel so down?" - Compare with these words of Abay. Again, Abay: "The ignorant country rejoices in something that does not rejoice, and when they rejoice, they do not know what to say, or what to do. And those who are ashamed are ashamed of what they are not ashamed of, and they are not ashamed of what they are ashamed of. All this is the effect of ignorance and stupidity. When you say that, some people say, "That's right, that's right". Don't believe him, tomorrow he will be one of them. Even though he is clear in mind, he can't stop himself from his original habit like an animal, he falls into a state of indecision, no one can stop him, and no one can explain him. No matter how bad the habit is, the Kazakh will stop when he is inevitably afraid of it or dies, otherwise, you will not see a person who has lost his mind, knowing that it is wrong, and stopped thinking on his own".

"Not looking critically at your people, the promotion of its "advantages" creates negative ethnic stereotypes," - said Professor A. Aitaly [7. 27].

Do our thoughts and actions about values agree? The answer is A. Aitaly explains: "Like the Kazakhs, who are not organized as a leading nation, the people become the support, not the support of another community. Like the economic, political and ideological pluralism that prevails in our country, ethnic pluralism is most compatible with the structure of our country. Today it is important to educate the citizens of Kazakhstan, not the nation of Kazakhstan" [7. 9].

"National consciousness, national worldview is innate in the people, so it is not as powerful as natural laws," he said. Agreeing with the words of Aitaly [7.28], one could understand how important it is to value and promote national values for the growth of national consciousness.

\section{DISCUSSION}

About valuation and value M. Heidegger's "Letter on Humanism” is thought-provoking: "Any assessment, - writes M. Heidegger, - even when the assessment is positive, there is subjectivities. It allows beings not to be, but, as an object of assessment, just to be considered. When God is ultimately declared to be "the highest value," it is a belittling of a divine being. Thinking in values here and in everything else is the highest sacrilege that is possible to be" [8. 47.].

Yes, even the best assessment is subjective.

Heidegger does not want to establish a universal hierarchy of values that covers all aspects of human life and even tries to avoid valuing what is the basis of social life. The deep foundations of social life in each specific period of history are perceived and felt by the person who lived at that time as something directly given to him, that is, as an objective thing. Social life, like the life of the individual, is a process of continuous change and change, often as a result of human activity. Major actions in society and social life are evaluated. It is useless to say that man evaluates all his daily actions, then the "reality of existence" would not be felt by him, he would live only in his fantasy world. At the same time, a person cannot sit still, so he must evaluate his actions. The search for truth does not always allow us to think about values.

In comparison with any object that mentally corresponds to an object, there is an evaluation relationship. The linguistic expression of a valued relationship is often reinforced by explicit or implicit statements that "it should be so."

Human life is intertwined with experience, which is based on work, recognition and naming the recognized object and phenomenon as a manifestation of the image of the world. To know the world is to know the truth, to strive for the truth. Recognition, aspiration on the way of striving - knowing. Knowledge in the way of knowing the truth, striving for goodness and morality, striving for truth is a value.

For example, we say that a person should be honest. But this is not the truth; it is a commitment to the highest goal of human nature. Not everyone is always honest. However, that does not prevent from saying that a person needs to be honest. Moreover, the more wicked people appear in society, the greater the demand for honesty.

We need to take care of our loved ones. But we should not say that the whole world is coming to us, that the key to the world is in our hands. For the idea of "Love all mankind, as your brother" as expressed by Hakim Abay for the benefit of mankind, it is important to study the humanistic ideas and principles in his poems in a new direction on new scientific theories. Has such a passionary attitude ever been expressed in the world?! The human factor is significant for modern society. It is essential to justify the appearance of personality, the ways to achieve a feeling of complete peace and become a full-fledged person through the concepts of warmth, radiant mind, and warm heart, proposed by Abay. It is known that issues such as "human life, "the 


\section{Evaluation of National Values and Abay's Teaching}

essence of human life" in the twentieth century in Europe formed the principles of existentialism. Existentialism seeks to solve many philosophical issues, such as self-knowledge, the meaning of life and death, the meaning of freedom, morality, mercy, beauty, justice and truth, the purpose of man's birth, his place in society. The sage Abay emphasizes the importance of selfesteem, the human superiority of self-esteem, the work of the intelligent soul, by saying, "Wise person can divide a small thing into forty, He will judge everything as judging himself". Therefore, it is necessary to distinguish between knowledge in the narrow sense and knowledge in the broad sense, which is always recognized as "knowledge of the truth", which includes not only truth but also goodness, beauty and virtue.

Value is one of the main universal concepts in the system of philosophical and humanitarian discourses. The term "value" is used to describe the human, social and cultural significance of a particular object or phenomenon.

Value is not only a matter of ethics and aesthetics or philosophy in general but also a matter of linguistics. If we say that there is a close connection between language and culture, language and cognition, the concepts that define the value are not only marked by language symbols but also stored in historical memory based on language units, radiated in consciousness. If we say that value is a phenomenon that connects the individual and the world, then we consider it scientifically important to define the importance of value as a denotation of names in the language, which is seen as a linguistic image of the world, and to consider lingua-philosophical, cognitive.

The concept of value is the basis that defines the human essence, the inner nature of man. In Kazakh, there is a concept of virtue, sacred and unholy, which is applied to a person. The meaning and significance of this are too deep. The system of values consists of a system of sacred concepts accepted in the human mind, which in itself creates the nature and essence of the inner nature of the person. For an individual to acquire qualities in his cognitive, cognitive activity, it is necessary to master these values. We believe that as a result of mastering and mastering values, a person is assessed as holy or unholy. Because there is no value without an appraiser. And to appreciate it, you need to hear, see, know, understand, and appreciate the value. Value is a spiritual creative phenomenon, a subjective experience. To evaluate things and phenomena as national values, human beings must be directly connected with that world and recognize it. And this knowledge, even if it is too high in value and too low in value, is a threat. We cannot deny that there is such a discrepancy in the assessment of national spiritual and cultural values in the Kazakh national worldview at the beginning of the XXI century.

An important feature of the assessment category is the recognition of the truth. The very disclosure of the recognized truth is subjective, that is, the assessment of the true event, action, important feature of being in the opinion of the individual, so even then the subjectivity is preserved. No matter what the assessment is, even if the subject is not clearly visible or mentioned, the evaluative relationship between the object and the subject is maintained. The personal opinion of the narrator or the writer is associated with his internal agreement or disagreement, and the likes/dislikes, evaluations/disapproval, consent/disagreement, etc. are shown based on such notions. About this E.M. Wolf conducted extensive research and gave a thorough opinion [1.p. 2433]. Agreeing with the conclusion of the scientist, it is appropriate to say that along with the subjectivity of the assessment, the inner feelings, emotion of the person have a special place in the conclusions of the assessment.

The role of emotion in the evaluation is closely related to the ability of a person to express his inner feelings in the right way, to represent them intelligently, to understand the action, to understand its meaning. Emotions are considered to be related not only to the senses but also to the mind. Actions and situations can be evaluated rationally and intelligently. This type of assessment has a complex semantic structure. Let's turn to Abay again:

A man is a sack of shit that he carries,

You'll stink of shit if you die again.

Being proud saying are you equal to me?

The sign of ignorance is that.

Yesterday you were a child; you lived many years now,

I was convinced that I could not standstill.

Love man, feel the wisdom of God,

What else is interesting in life?! (Meaning translation by authors)

The meaning of the poem is complicated. It is a poem that requires straightforward thinking and deep intellect to reach the bottom of the truth, which you do not want to accept even if you know it, which you cannot say, that breaks down the walls of human nature and reveals the truth. In our opinion, the evaluation of the text of the poem is dominated by the emotional component. The inner nature of the image of the world in the human mind is clearly marked, and the image of reality is clearly depicted. Rational thinking seems to correspond to rational thinking. "A man is a sack of shit that he carries" - do you disagree with the poet? Think, understand, understand, and agree! 


\section{Evaluation of National Values and Abay's Teaching}

"Being proud saying are you equal to me?" - is a sign of ignorance. It is worth thinking again. There are many such people around us. The Kazakh worldview would say, "The good can't say I'm good, the bad can shout I'm good". The expression of thought and action is thus marked, refined, and re-influenced by the linguistic image of the inner world. The text of the poem indicates the author's criteria (limits) for determining the meaning of human life. A wise choice in the author's assessment: "Love man, feel the wisdom of God". You will understand, acknowledge and be amazed that the appropriate use of words, the semantic structure of verbs accurately reflects the meaning of the formed idea is an expression that can be achieved not only by great talent but also by a wise man. You feel happy! You appreciate it! The reason for your joy is to see and appreciate the human values created by the Kazakh worldview, in the Kazakh understanding, in the Kazakh language, and to express the feeling of selfless gratitude.

Love man, feel the wisdom of God,

What else is interesting in life?!

This is the conclusion of the poem. It is not for young people, children, rather it's for open-minded who have lived for many years. The semantic connection between the deep semantic structure of the verbs "love" and "feel" in the phrases "to love man", "to feel the wisdom of God" and the meaning of the phrase is so clear, precise and successful. Is there anything better than a "loving man"? The main thing that everyone can do is to start with love and end with love, isn't it?! Loving a person is like a circle at the top of the list of virtues. Where there is love, there is no place for evil. If "love" is false, a red dog called "jealousy" will follow, and it will bring other evils and create its own triumph. In that case, there is no room for "faith". The semantic meaning of the verb "feel" in the phrase "feel the wisdom of God" is also special. It is clear from the verse that by experiencing the wisdom of God, your understanding of the meaning of life will change.

The correspondence of the assessment in the text of the poem with the real, human nature is a manifestation of objectivity and a clear reflection of the subjective point of view. This is again since human beings are based on the current real situation. " $A$ man is a sack of shit that he carries. You'll stink of shit if you die". The human condition is such that it concerns the physiological body of man; "Being proud saying are you equal to me? The sign of ignorance is that" - a person's psychological state. By living life, human beings do communicate, see or talk with anyone! Probably, I have not seen a single Kazakh child who is not proud or can't be proud. Sage Abay was right, it is a human quality that has penetrated the national spirit. Proudly, I look at the steppe, proudly look at the city, proudly build a tall house, and proudly build a mosque, proudly ... proudly...

Yes, so is there a lie in the words of the sage Abai, or can you say that it does not apply to me? The criterion that determines the main content of the assessment is the fact that it is based on everyday situations and real actions. Now let's look again at the conclusion or results of the assessment:

Love man, feel the wisdom of God,

What else is interesting in life?!

This is Abay's assessment. The choice is for the benefit of mankind. It is necessary to dig deep into the text of the poem. In our opinion, there is epistemological rationality. Epistemological rationality brings together and strengthens the connection between the image of the world and the world itself in the human mind. The poet's statement has a doctrinal significance. "What else is interesting in life?!" By saying, the poet summarizes his conclusion, his connection, because this conclusion is based on doctrine, knowledge, experience. By thinking rationally, a person would not make mistakes in his life, only a person who firmly and thoroughly recognizes, knows, accepts the truth around him, and correctly identifies the situation, can think positively, look correctly and draw clear conclusions. There is no ambiguity in Abay's assessment. Concise predicate persons despite their ambiguous nature, have a definite meaning in the text and mark only one concise idea. Love man, feel the wisdom of God, What else is interesting in life?! - The semantic structure of the predicate persons "love", "feel", "there is" in the sentence is clearly used in this context in the singular sense, it is impossible to understand the persons in this phrase ambiguously or interpret the pragmatic meaning differently.

Knowledge is also needed to think deeply about the meaning of each word. Knowledge is also needed to understand what is being said and to draw conclusions from it.

Abay says:

A word from a knowledgeable person

May it meet an inquisitive one?

To see the light, the secret

May his heart will be open.

The heart is a mirror, the mind is awake,

He won't listen to word slowly.

His art is close by, 


\section{Evaluation of National Values and Abay's Teaching}

Shouldn't he understand the word fast? (Meaning translation by authors)

The meaning of thinking is in every word, in every morphological structure and syntactic phrase, in the package. The meaning of the text is formed by the unit of the semantic structure of those persons. It is better to recognize and analyze the relationship between thought and language, rather than to understand and search only theoretically. The meaning of the text is in the meaning of the people who make it up. It is known that the listener does not analyze the meaning of individual words or grammatical figures to understand the idea, but the meaning of the text is also important for the listener. However, the basic and primary information conveyed through the grammatical structure is stored in the original consciousness of the person who speaks the language, and in the perception of thought, this cognitive information is added and allows understanding and perceiving the general content. Automation in language acquisition (especially in learning other languages) is understood as the collection of information in this original consciousness. Because lexical, grammatical, and phonemic information in the mother tongue is absorbed with breast milk, the student or listener can perceive the vocabulary as a whole, without taking it separately. Can perceive a sentence, context as a whole, and explore its inner meaning. Probably, this is the main difficulty in learning a second language or another language and receiving textual information in it.

In order to understand the meaning of the above-mentioned lines of Abay's poem "A word from a knowledgeable person, may it meet an inquisitive one" (Bilimdiden shiqqan soz, talaptiga bolsin kez), the reader must know whether the suffixes "-im" and "-di" are connected to the root "bil" and form a derivative word or "den". It is not the basic and necessary information that connects and gives directional meaning. The reader takes the word "knowledgeable" (bilimdiden) as a whole and understands its contextual meaning. The word of knowledge requires reading the whole sentence, even if it is required, to understand the content of the thought, the inner meaning of the text. As an example, there are no words in the sentence that are good / bad, like / dislike. However, there is an assessment in the content of the text. It is an assessment in the general logical connection of thought, in the content of thought, and thus in the internal meaning conveyed. First of all, the text has its own special pragmatic meaning. It is known that this is a property that can be found in any text. The main pragmatics of the poem is in the fact that the spoken word comes from the ear, is absorbed, is woven intelligently. The poet can appreciate his words and thoughts. He seeks the soul with the eyes in his heart, so that he understands the secret of his word and understands the light of the beam, and dedicates the word of the secret to it. This assessment is marked by the word "knowledgeable" and really illuminates. The semantics of assessment and its structure in the word create such a peculiar pragmatic situation. Therefore, there is a poetsubject with deep knowledge. It provides the necessary conditions for the level of the listener, the student. It is a condition - the heart - a mirror, the mood - to be vigilant, demanding person. Although the poem is written in the form of a monologue, there is a situation in which two main actors take part - the poet, who is the subject of further evaluation; the second is the addressee, the student, the listener (this opinion is intended, but does not have to be a form of assessment). Assessment is thus expressed in language.

\section{CONCLUSION}

The predicates that define and specify the essence of the assessment reflect the nature of the basic pragmatic meaning. By the reality of human existence, the pragmatic meanings of the people used are fully understood by people in society and are close to their worldview and outlook on life. It is obvious that the idea of feeling God's wisdom and loving people did not start only with Abai, but also with the wisdom of the Kazakh worldview, Kazakh proverbs, works of poets. Abai's novelty is in his new assessment, that is, in the delivery of new knowledge, new forms, new results, absorbing the previously expressed knowledge, the acquired language experience and a rich taste in the system of thinking. Cognitive experience is the basis, motivated and presented to the people in a new quality. Obviously, we cannot say that the idea in the text is completely new, but the importance of careful assessment is in its clarity and accuracy. There is no room for ambiguity, the use of the phrase "in this life" simultaneously masters the concept of time and space. M. Bakhtin's notion of a place of residence is conveyed through the person of "this life", which holds both time and space at the same time, and does not hold the sensible, straightforward listener at the same time. Abai is not convinced that this is possible, but he is convinced of the clarity and correctness of his thoughts, so his assessment is clear, this is the link between the main idea of the objective reality.

In national cognition it is necessary to accept Abai's assessment at the level of "axiological field", to widely use and propagate the nature of assessment, the essence of the connection with reality in the formation of the individual. Axiology is the study of the nature of values, the structure of world values and their place in real life, while Abai's teachings and assessment system should form the basis of the Kazakh national axiological field. It is well known that most of the ideas about value, goodness, and profit came from sages, and Socrates was recognized as one of the first commentators on value. Wealth is a real value, a benefit. Profit and value are valued in philosophy as two sides of the same coin. Valuable conclusions arising from Abai's thoughts and embroidered in the lines of the poem will appear if the Kazakh spiritual value, that is, the spiritual and cognitive 


\section{Evaluation of National Values and Abay's Teaching}

activity is valued and served as a human good. Because there is a reassessment of the accumulated spiritual values because there is a mental assessment of national psychology and intelligence.

\section{REFERENCES}

1) Aitaly A. The nation is a great cooperation. // “Aktobe newspaper” January 30. 2014. p.2. (Айталы А. Ұлт дегеніміз ұлы ынтымақтастық. // «Ақтөбе газеті». 30 қаңтар. 2014. https://aqtobegazeti.kz/?p=25409)

2) Gumilev L.N. About the term "ethnos" http://gumilevica.kulichki.net/articles/ Article84.htm (Гумилев Л.Н. О термине «этнос». -M., 1966. http://gumilevica.kulichki.net /articles/ Article84.htm)

3) B.V. Andrianov Problems of the formation of peoples and nations in African countries. - "Questions of history", 1967, № 9.; р. 102; 226, -р. 52-53; (Андрианов Б.В. Проблемы формирования народностей и наций в странах Африки. «Вопросы истории», 1967. -№ 9.; стр.102; 226, -С. 52-53;)

4) Tokarev S.A. The problem of types of ethnic communities. - "Questions of Philosophy", 1964, - No. 11. -p.123-125. (Токарев С.А. Проблема типов этнических общностей. - «Вопросы философии», 1964, - №11. -С.123-125.)

5) Aitaly A.A. Nation studies. - Almaty: Arys, 2000. - 223 р. (Айталы А.Ә. Ұлттану. - Алматы : Арыс, 2000. - 223 б.)

6) Axiology. Philosophy: Encyclopedic Dictionary. -М., 2004.1072 р. (Аксиология. Философия: Энциклопедический словарь. -М., 2004. 1072 с.)

7) Ivin A.A. Axiology. - М., 2006. р. 28-45. (Ивин А.А. Аксиология. - М., 2006. С. 28-45.)

8) http://www.bibikhin.ru/pismo_o_gumanizme Translation by V. V. Bibikhin Source: Martin Heidegger "Being and Time". Moscow, publishing house "Republic", 1993 (Хайдеггер М. Бытие и время. -М.: Республика, 1993. http://www.bibikhin.ru)

9) Wolf E.M. Functional semantics of evaluation. M.: "Science", 1985. p. 24-33. (Вольф Е.М. Функциональная семантика оценки. -М.: «Наука», 1985. с. 24-33.)

10) Bakhtin M.М. To the methodology of literary criticism. Context. Literary theoretical research. М., $1975 ., 386$ р. (Бахтин М.М. К методологии литературоведения. Контекст. Литературно-теоретические исследования. -М., 1975. 386 С.) 